\title{
Linkage Analysis between Solid-Fluid Coupling and the Strength Reduction Method for Karst Cave Water Inrush in Mines
}

\author{
Yanlin Zhao iD, Jian Liao, Qiang Liu, Yang Li, and Jianchao Cheng \\ Hunan Provincial Key Laboratory of Safe Mining Techniques of Coal Mines, \\ Work Safety Key Lab on Prevention and Control of Gas and Roof Disasters for Southern Coal Mines, \\ Hunan University of Science and Technology, Xiangtan, Hunan, China \\ Correspondence should be addressed to Yanlin Zhao; yanlin_8@163.com
}

Received 15 January 2020; Accepted 3 February 2020; Published 4 June 2020

Academic Editor: Longjun Dong

Copyright (C) 2020 Yanlin Zhao et al. This is an open access article distributed under the Creative Commons Attribution License, which permits unrestricted use, distribution, and reproduction in any medium, provided the original work is properly cited.

\begin{abstract}
The present paper aims to study the mechanical mechanism and characteristics of water irruption from Karst cave. Combining the nonlinear seepage-pipe coupling model with the strength reduction method, the linkage analysis of fluid solid coupling and strength reduction method are constructed to study the whole process of confined Karst cave water inrush. Taking the water inrush accident of Shibaijing of the Qiyi mine in south China as an example, the instability mechanism of the water-proof rock pillar and evolution of water inrush are discussed. It is suggested that water discharge on the working face augments with the increase in the reduction factor of the water-proof rock pillar before the rock pillar loses its stability. Once the rock pillar becomes unstable, Karst water bursts from confined Karst cave in a pipe flow shape, and the water irruption quantity reaches the peak value in a short time by adopting the pipe flow to simulate and then decreases slowly. The hydraulic rough flow at the initial stage changes into pipe laminar flow finally in the process of Karst water inrush, due to the constraint of Karst cave water reserve. The conception for the safety factor of the water-proof rock pillar introduced, the relation of the safety factor, Karst cave water pressure, and thickness of the water-proof rock pillar are studied. It is proposed that thickness of the water-proof rock pillar whose safety factor equals 1.5 is regarded as the calculating safety thickness of the water-proof rock pillar, and the safety thickness of the water-proof rock pillar setting in mining engineering should be equal to the sum of the blasthole depth, blasting disturbance depth, and the calculating safety thickness. The reason leading to Karst water inrush of Qiyi Mine is that without advanced boreholes, the water-proof rock pillar is set so small that it could not possess safety margin, so the confined Karst cave water breaks the water-proof rock pillar and bursts out. Combining the solid fluid coupling theory, pipe flow theory, and strength reduction method, the nonlinear mechanical response of confined Karst cave water inrush is studied, which provides a new study method for the whole process of confined Karst cave water inrush.
\end{abstract}

\section{Introduction}

China owns many types of coal-bearing basins and has large amounts of coal resources. The stress and hydrogeological conditions are extremely complex during deep mining, and especially, one of the main challenges associated to deep mining is the increased water pressure. The coal production reached 3,700 million tons in 2012. Water inrush into coal mines is regarded as a serious detriment to mining safety. In China, there have been thousands of casualties in groundwater-related coal mine accidents since 2000. Among underground engineering accidents, including water rush
[1-4], gas explosion [5], rock burst [6-8], and time-dependent large deformation [8-10], the groundwater inrush in coal mines is second only to gas explosion in causing catastrophic accidents according to government statistics (State Administration of Coal Mine Safety 2008). Mining depths and mining intensity have increased, causing the encountered hydrogeological conditions to become more complicated. Water inrush threatens mine safety and coal mine productivity $[11,12]$. Geological settings and hydrogeological conditions of the coalfields in China are very complicated. The coalfields in north China are typical permian-Carboniferous coalfields. Many coal seams lie 
above the Ordovician limestone which is a highly permeable confined aquifer. Because of the potential impacts of the confined water in the Ordovician limestone on the mining activities, the coal seams, accounting for $37 \%$ of the total reserve, are listed as prospective reserves in north China $[11,12]$.

The coalfields in south China locally occurred in late permian. Figure 1 shows the representative stratigraphic column of the region [13]. The main minable coal layer lies in the late permian Longtan Formation. The overall coal products of this region account for a small part of the national total coal production. Hydrogeologically, south China is in humid region and dominated by modern Karst terrains. Coal excavation from late permian Longtan formation is seriously threatened by lower Maokou Karst aquifer and upper Changxing Karst aquifer. All the times, the key issue in south China is to prevent late permian Karst water bursting.

The Karst groundwater is mainly of the dissolved-cavern type and Karst-fissure type and usually forms the complicated systems of Karst fissures, dissolved cavern pipes, and Karst caves in south district [14]. The distribution and structure of underground water system are obviously of inhomogeneity, and this brings the anisotropism that the underground hydrodynamic force is connected. Although the Ordovician limestone in north and the Maokou limestone in south are both aquifers, there exist great differences between them. In north, its Karst underground is mainly of the Karst-fissure water-bearing type. Its hydraulic slope is rather soft, belonging to unified confined water-logged strata, and once the water is exposed, serious water inrush accidents happen, giving rise to the decline of water level of aquifer [15]. As for the southern area, particularly in the Songzao Mine Area in Chongqing city, Doulishan Mine Area in Hunan province, and the north area of Guizhou province, water filling Karst caves generally exist in the Maokou limestone; moreover, the horizontal hydraulic relation among Karst caves is weak and relative independence, which cannot form unified aquifer system [16-19]. With regard to the Maokou limestone of the basement in southern coalfield, its inhomogeneity of karst development in space distribution is found. When Karst is least developed, Maokou limestone strata can be seen as a relative impermeable layer. So, Maokou limestone strata can be fully utilized by adopting a scientific method. At present, development roadways are arranged in Maokou limestone strata in many southern coalfields, such as Xingwujing mine of Nantong Company in Guizhou province, Shipingyi mine of South Sichuan Coal Industry, Meitanba mine in Hunan Province, Huayingshan mine of Chongqing city, and so on $[14,18,19]$. While the Karst cave development area is the major hidden trouble for mine water inrush, Karst cave water inrush is seen as one of the coal mine flood accidents in south China, which generated to a large amount of economic loss, such as the "4.16" accident happened in the Qiyi mine of Hunan Province in 2003 (17 people died), "9.28" Karst cave water inrush accident happened in the Xinmao mine of Hunan Province in 2010, and "12.12" Karst cave water bursting in the Tianchi mine of Guizhou Province

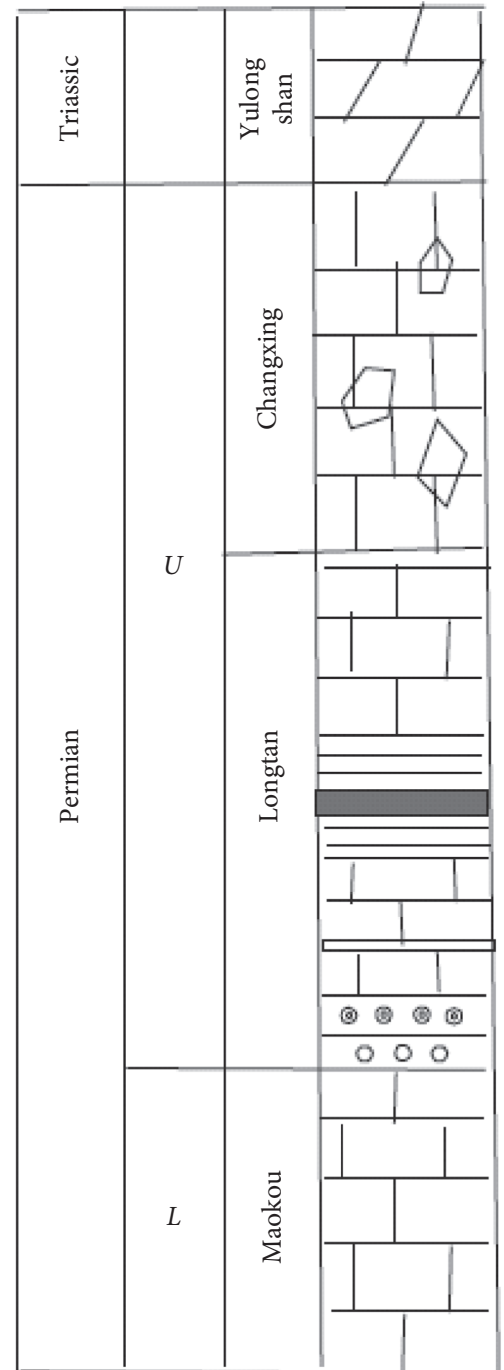

FIgURE 1: The representative stratigraphic column of the coalfields in south China.

in 2004 (21 deaths and 15 missing), which were typical Karst cave water inrush accidents in late Permian Maokou limestone.

The rock strata between the working face and Karst cave act as a geological barrier that prevents Karst cave water from invading into the roadways. The effectiveness of the geological barrier depends on its thickness, lithology, and integrity $[20,21]$. Water inrushes are likely to occur when the geological barrier is too thin to withhold the pressure of Karst cave water. In a Karst mine, the main technique for controlling water inrush is to leave a sufficient thickness of the water-proof rock pillar. While the calculating method about safety thickness of rock pillar setting for confined Karst cave is not given in regulations of mine water control of China [22], a study on stability of the water-proof rock pillar and its safety thickness is of great significance for controlling Karst water inrush in a mine. In order to do so, it is of vital importance to study strata failure characteristics and hydraulic conductivity changes due to mining and thereafter find a way to predict and prevent water inrushes. 
Various research studies have been conducted in this area [23-26]; however, the mechanism of water inrushes is still not well-understood. In this paper, linkage analysis between solid-fluid coupling and the strength reduction method based on flow state conversion theory is adopted to discuss the stability of the water-proof rock pillar. Meanwhile, the concept of safety factor of the water-proof rock pillar introduced, and the safety thickness of the water- proof rock pillar setting in mining engineering is proposed.

\section{Solid-Fluid Coupling Mechanism of Confined Karst Water Inrush}

When a confined Karst cave is concealed before a roadway, disturbance stress evokes the sharp change of stress field and seepage field of surrounding rocks. There would be strong coupling effect in the surrounding rock mass between the Karst cave and working face. This kind of coupling effect is shown as follows: (1) the action of a high hydraulic gradient (high seepage stress) on the surrounding rocks results in the change of stress field; (2) also, due to mining-induced fissures in the surrounding rocks under high hydraulic pressure and disturbance stress field, the hydraulic conductivity of the surrounding rocks augments greatly. The schematic diagram for a water-proof rock pillar is shown in Figure 2. From the angle of rock mass fluid mechanics, under disturbance stress and high hydraulic pressure, confined Karst cave water inrush can be considered as a catastrophic instability of the water-proof rock pillar between the Karst cave and working face, accompanying with Karst cave water inrush.

2.1. Elastic-Plastic Analysis for a Water-Proof Rock Pillar of a Confined Karst Cave. Constitutive relation of elastic-plastic mechanics for rock mass under coupling effect of stress field and seepage field can be denoted as

$$
\sigma_{i j, j}+F_{i}+(\alpha p)_{, j}=0,
$$

where $(\alpha p)_{, j}$ is equivalent volumetric stress acting on the water-proof rock pillar, which reflects the coupling effect of seepage field on stress field.

Yield criterion is the Mohr-Coulomb Criterion, and the shear failure criterion is represented as

$$
f^{s}=\sigma_{1}-\sigma_{3} \frac{1+\sin \phi}{1-\sin \phi}+2 c \sqrt{\frac{1+\sin \phi}{1-\sin \phi}}=0 .
$$

The tensile failure criterion is that

$$
f^{t}=\sigma_{t}-\sigma_{3}=0,
$$

where $\sigma_{1}$ is the first effective principal stress, $\sigma_{3}$ is the third effective principal stress, $\phi$ is the internal friction angle of the rock mass, $c$ is the cohesion, and $\sigma_{t}$ is the tensile strength.

2.2. Nonlinear Seepage-Pipe Flow Coupling Based on Flow State Conversion Theory. The essence of Karst cave water inrush is the instability of the water-proof rock pillar. When the rock pillar is unstable, the flow discharge of working face

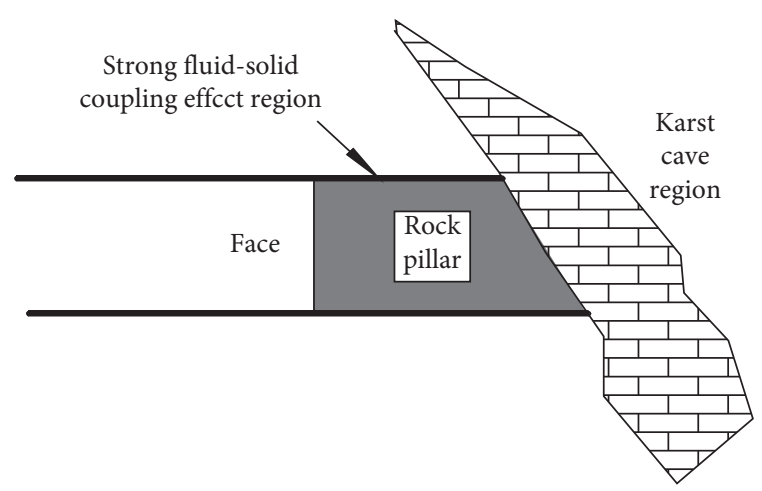

Figure 2: The schematic diagram for a water-proof rock pillar.

is in the form of seepage and small-scale water flow. Once the water-proof rock pillar becomes unstable, the water in the confined Karst cave bursts in the form of pipe flow.

2.2.1. Water-Proof Rock Pillar Instability. When the elasticplastic calculation for the water-proof rock pillar is convergence, the water inflow form is hydraulic seepage, and the differential control equation for seepage analysis of the surrounding rocks is represented as

$$
\frac{\partial p}{\partial t}=-u_{s} \frac{\partial}{\partial x_{i}}\left(k(\Theta, p) \frac{\partial p}{\partial x_{j}}\right)
$$

where $p$ is the seepage pressure, $k(\Theta, p)$ is the hydraulic conductivity, and $u_{s}$ is the storage coefficient.

The influence of seepage pressure and stress field on the hydraulic conductivity can be presented as $[27,28]$

$$
k(\Theta, p)=\xi k_{0} e^{-(\Theta / 3-\beta p)},
$$

where $k_{0}$ is the initial value of the hydraulic conductivity, $k(\Theta, p)$ is the hydraulic conductivity by means of coupling analysis, $\Theta=\sigma_{1}+\sigma_{2}+\sigma_{3}$ is the volumetric stress, $\xi$ is the sudden jump coefficient of the hydraulic conductivity, and $\beta$ is the coefficient.

In coupling analysis, for elastic units, the hydraulic conductivity is looked as the negative exponential function of the volumetric stress. In equation (5), $\xi$ is 1.0 and $\beta$ is 0.5 .

For plastic yielding units, the hydraulic conductivity enhances greatly. The sudden jump coefficient of the hydraulic conductivity enhances obviously. In equation (5), $\xi$ is 1000 and $\beta$ is 1.0 .

Equation (5) reflects the coupling effect of rock mass stress field on seepage field. Particularly, the strong coupling effect of plastic units on seepage field is reflected.

2.2.2. Water-Proof Rock Pillar Instability. When the elasticplastic calculation has no convergence, the water-proof rock pillar is unstable, and Karst cave water bursts out to the roadway; the governing law for water inrush was studied by using the pipe flow model.

Nonlinear pipe flow is a complex problem educed from the Darcy-Weisbach equation: 


$$
\Delta H=f \frac{l}{d} \frac{u^{2}}{2 g},
$$

where $\Delta H$ is the head loss, $f$ is the friction factor of head loss, $l$ is the length of the pipe, $d$ is the inside diameter of the pipe, $u$ is the mean flow velocity in the pipe, and $g$ is the acceleration due to gravity.

The Reynolds number, Re, in the process of water inrush is represented as

$$
\operatorname{Re}=\frac{\rho v d}{\mu}
$$

where $\rho$ is the density of water, $v$ is water velocity in the water inrush channel, and $\mu$ is the dynamic viscosity of water.

Based on Nikuradse's experimental curves, when $\operatorname{Re}>100000, f$ is related to relative roughness of the pipe wall, but it is independent of Re; under this situation, head loss $\Delta H$ has direct ratio relations with $u^{2}$, namely, "the hydraulic rough region", and the following equation can be attained by using the Von Karman equation:

$$
f=\frac{1}{[1.74+2 \lg (2 \Delta / d)]^{2}},
$$

where $\Delta$ is the roughness of the roadway.

When $\operatorname{Re}<2300$, the friction factor of head loss can be obtained by the Hagen-poiseuille equation:

$$
f=\frac{64}{\operatorname{Re}} \text {. }
$$

In this case, $\Delta H$ has a direct ratio relation with $u$, belonging to "the laminar region".

When $2300 \leq \operatorname{Re} \leq 100000$, the friction factor of head loss can be obtained by the Blasius equation:

$$
f=\frac{0.326}{\operatorname{Re}^{0.25}} \text {. }
$$

In this case, $\Delta H$ has a direct ratio relation with $u^{1.75}$, belonging to "the hydraulic smooth region".

During the process of Karst water inrush, flow velocity is fast at the initial water inrush, the diameter of water-burst channel is big, and the Reynolds number, Re, is much more than 100000 in the process of initial water inrush. So, the initial water inrush belongs to the hydraulic rough region. With the development of water inrush, the Karst cave water pressure drops off due to the limit of aquifers reserve in the Karst cave, and flow velocity in the roadway will become slower, the water flow in the roadway will transform from "the hydraulic rough region" into "the hydraulic smooth region" or even "the laminar region".

With regard to a noncircular roadway, the equivalent diameter of the roadway is used which can be denoted as

$$
d=\frac{4 S}{U}
$$

where $S$ is water-carrying section areas and $U$ is the wetted perimeter.

If $\mathrm{T}=$ the porosity of pipe flow $n=1$, then $V=u$ equation (6) can be expressed as follows $[25,26]$ :

$$
V=\frac{2 g d}{f V} J=\frac{8 g S}{f V U} J .
$$

Comparing equation (12) with the Darcy law, the equivalent hydraulic conductivity of pipe flow is defined as follows:

$$
K_{L}=\frac{8 g S}{f V U} .
$$

When the pipe flow is in the turbulent state, the flow law of pipe flow can be expressed to the nonlinear Darcy's law by substituting the equivalent hydraulic conductivity $K_{L}$ for $k(\Theta, p)$ in equation (4).

If water flow is in the laminar state, the equivalent hydraulic conductivity $K_{L}$ transforms into the true hydraulic conductivity $K_{L 1}$ by submitting equations (9) into (13):

$$
K_{L 1}=\frac{d^{2} \rho g}{32 \mu}=\frac{S^{2} \rho g}{2 U^{2} \mu} .
$$

The conception of equivalent hydraulic conductivity $K_{L}$ is introduced to equation.(4), and laminar region and turbulent region in the roadway are expressed with a unified law:

$$
\frac{\partial p}{\partial t}=-u_{s} \frac{\partial}{\partial x_{i}}\left(k \frac{\partial p}{\partial x_{j}}\right)
$$

where the hydraulic conductivity of water-proof rock pillar instability is $k=\xi k_{0} e^{-(\Theta / 3-\beta p)}$, while for an unstable waterproof rock pillar, equivalent hydraulic conductivity $K_{L}$ which is considered to the hydraulic conductivity $k$ in equation (15) is adopted to describe pipe flow in the roadway.

2.3. Solid-Fluid Coupling Program Designing. The solid-fluid coupling analysis for confined Karst water inrush in a mine is conducted by the indirect coupling method. Firstly, the elastic-plastic stress field is calculated when time is $t_{i}$, then the hydraulic conductivity of surrounding rocks is obtained by using equations (5)-(14), which is delivered to seepage field calculation module, and then the coupling of stress field to seepage field is implemented. Secondly, the seepage volumetric stress obtained in seepage field acts on elasticplastic stress calculation units, and then the coupling of seepage field to stress field can be implemented. The calculation does not stop until reaching desired calculation time.

If the calculation has no convergence, Karst cave water inrush occurs and forms pipe flow, and the equivalent hydraulic conductivity $K_{L}$ of pipe flow is gained by FISH in FLAC $^{3 \mathrm{D}}$ based on equations (13) and (14).

Based on the thought of program development given above, combining nonlinear seepage flow and pipe flow, the solid-fluid coupling analysis program is successfully conducted in FLAC ${ }^{3 \mathrm{D}}$. This program is composed of three parts: an elastic-plastic stress calculation module, seepage calculation module, and coupling analysis module. The program flow chart is shown in Figure 2. 
The indirect coupling analysis method developed by FLAC $^{3 \mathrm{D}}$, of which merits are the fact that the coupling parameters (for example, the hydraulic conductivity and seepage volumetric stress) evolve with the time steps, the coupling message of every subcoupling system (subseepage system and elastic-plastic stress system) can be delivered accurately with time steps.

As for pipe flow, the corresponding equation is selected to calculate equivalent hydraulic conductivity $K_{L}$, based on the Reynolds number, Re. From the analysis mentioned above, pipe flow of water inrush is not only considered to have great "permeability" but also its equivalent hydraulic conductivity varies with the Reynolds number, Re, and it is not a constant. However, node flow rates are unknown numbers in the first time step; thus, the solving has to be carried out by an iterative method. Owing to the fact that initial Karst cave water inrush belongs to the turbulent rough region, $K_{L}$ is assumed to be the equivalent hydraulic conductivity of the hydraulic rough region. Through the given initial velocity of fluid flow $V_{i n}$, roughness $\Delta$ of water inrush channel (roadway), water-carrying section areas $S$, and wetted perimeter $U$ of the roadway, the equivalent hydraulic conductivity $K_{L}$ is firstly gained. Water pressure $p$ and flow velocity $V$ of calculating elements are obtained by FLAC ${ }^{3 \mathrm{D}}$. Then, the Reynolds number, Re, dependent of velocity Vobtained by FLAC ${ }^{3 \mathrm{D}}$ is used to judge the laminar region or turbulent region. The friction factor of head loss $f$ is calculated based on Reynolds number, Re. Then, the equivalent hydraulic conductivity $K_{L}$ for the next step is determined by using equation (13). By the method given above, the equivalent hydraulic conductivity $K_{L}$ evolves with the calculation time step as shown in Figure 3.

2.4. Linkage Analysis Between Solid-Fluid Coupling and the Strength Reduction Method. The basic principle of the strength reduction method is that shear parameters $c$ and $\tan \varphi$ are divided by reduction factor $F_{i}$, and a new group of value $c^{\prime}, \varphi^{\prime}$ is obtained, which is served as new calculation parameters $[29,30]$ :

$$
\begin{gathered}
c^{\prime}=\frac{c}{F_{i}}, \\
\varphi^{\prime}=\arctan (\tan \varphi / F)_{i} .
\end{gathered}
$$

In the strength reduction method for stability of a waterproof rock pillar, the shear parameters $c$ andtan $\varphi$ of the rock pillar do not reduce continuously until critical state.

Combing the solid-fluid coupling model and strength reduction method, the linkage analysis model between solidfluid coupling and strength reduction method for confined Karst cave water inrush was established. The process of realization is illustrated in Figure 4.

It is noted that although the instability of water-proof rock pillar is also related with the time-dependent failure, tensile failure, and crack coalescence process of water-proof rock pillar [31-34], in this study, the plastic coalescence failure of the water-proof rock pillar is considered based on the strength reduction method.

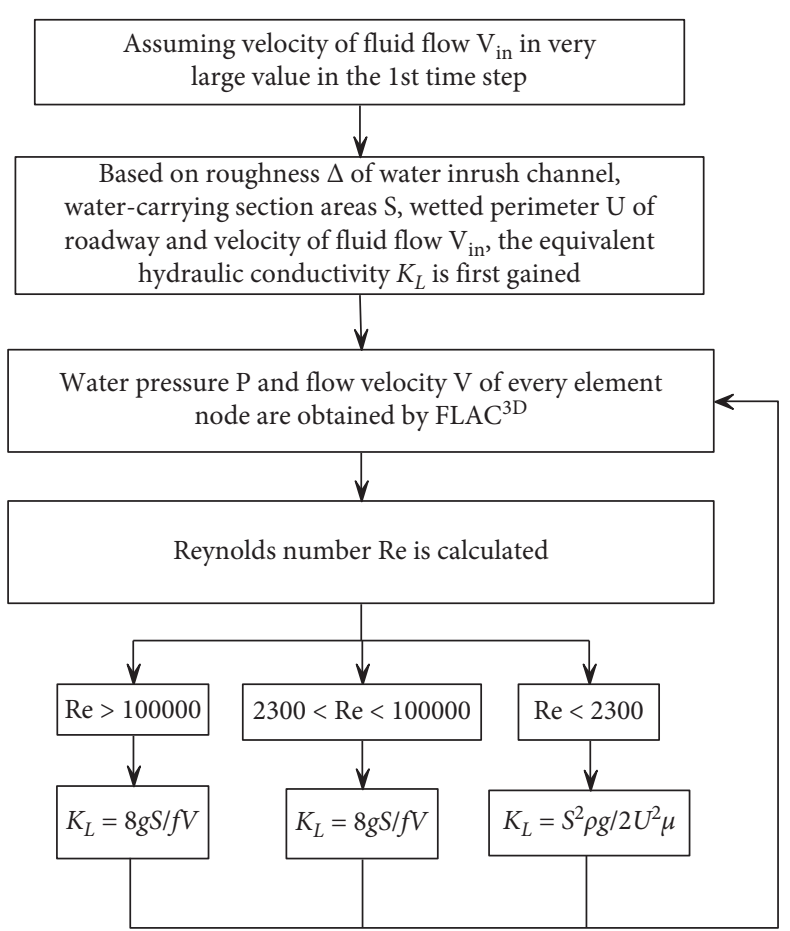

FIgURE 3: The equivalent hydraulic conductivity $K_{L}$ evolved with calculation time step.

\section{Case Analysis}

3.1. Water Inrush Accident. An example of the accident of confined Karst cave water inrush in the Qiyi mine in Hunan Province was studied in this paper. Karst cave water inrush happened on the heading face in the Qiyi mine with $-160 \mathrm{~m}$ level, which was a typical example of water bursting from confined Karst cave. The hydrological condition of the mine is very complex. Maokou limestone strata which is a confined aquifer under lies in coalseam 2. Karst caves in Maokou limestone strata always exist in the shape of moniliform structures, whose volumes are in state of half filling or full filling. However, water flow in Maokou limestone strata is less, and the Maokou limestone is a hard substance where Karst structures are less developed. The heading face with $-160 \mathrm{~m}$ level is in No.23 mining area located in Maokou limestone strata. On 16th April 2003, at 8 am 19 pm, Karst cave water poured into the heading face. On 16th April at $8 \mathrm{am}$, the water-proof rock pillar between the working face and confined Karst cave could not withstand the water pressure in the Karst cave, and so the water-proof rock pillar was broken at the length. A loud sound that was heard when the water inrush occurred indicated a sudden fracturing of the rock pillar and a sudden releasing of deep groundwater pressure with abundant of water burst from Karst cave all of sudden. The inflow occurred at an estimated rate of $3,670 \mathrm{~m}^{3} / \mathrm{h}$ at the very beginning. After about 2 hours, water raised as much as $2.5 \mathrm{~m}$, and flooded about $2 \mathrm{~km}$ of the roadway. The water flow was turbid along with small pieces of limestone, rock flour, and Karst breccias. In an accident, 17 people died. About $22500 \mathrm{~m}^{3}$ water in total burst out within nearly $11 \mathrm{~h}$. A Karst cave with volume about 


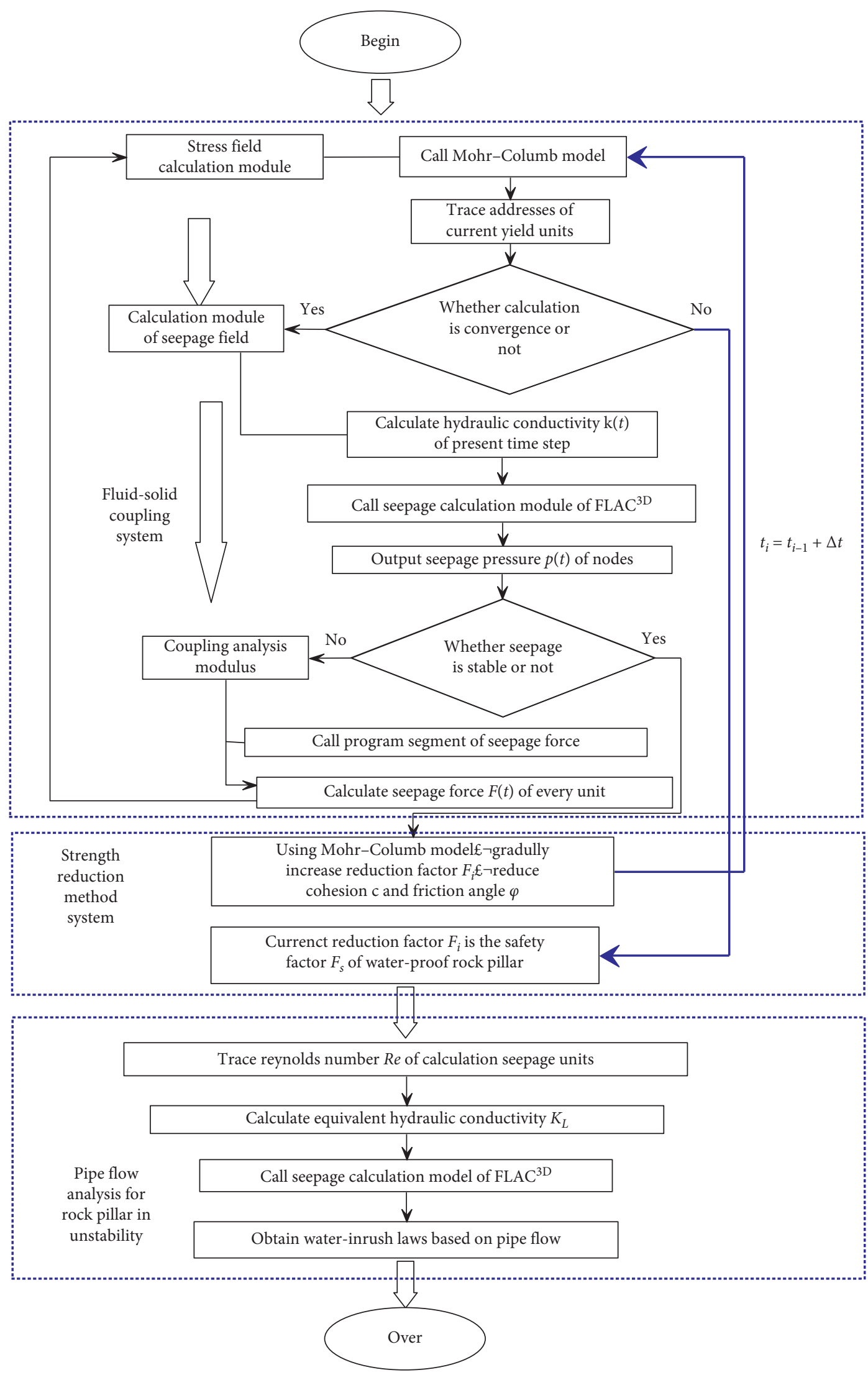

FIGURE 4: Flow diagram of linkage analysis between solid-fluid coupling and the strength reduction method based on flow state conversion theory. 
$20 \mathrm{~m} \times 6 \mathrm{~m} \times 20 \mathrm{~m}$ was exposed about $3 \sim 4 \mathrm{~m}$ before working face after slag clearing. The geological survey indicated that there were some major fractures and well-developed Karst caves around the roadway where water inrush took place, the deep confined Karst cave system exists in Maokou limestone strata in synclinal shaft of Doulishan coal mine area. The buried depth of roadway excavation is $450 \mathrm{~m}$ more or less. The hydrostatic pressure head is about $400 \mathrm{~m}$, the water pressure in the confined Karst cave in Maokou limestone strata is about $4.0 \mathrm{MPa}$.

Figure 5 illustrates the picture of water discharge of the roadway $8 \mathrm{~h}$ after water inrush. By means of spot investigation after slag clearing, it was found that the Karst cave was strongly dissolved, whose walls were smooth as shown in Figure 6, the Karst water was supplied by Karst pipelines, and the Karst cave was filled with a large amount of water and yellow mud. Figure 7 is the vertical plane projection of Karst cave development.

Maokou limestone specimens were sampled from the water inrush Karst cave. It was discovered that abundant Karst fissure and pores exist in the limestone near the confined Karst cave. As the surrounding rocks near the Karst cave were deeply dissolved, its integrity and continuity were poor with high porosity and developed fissures, while the mechanical properties of Maokou limestone far away from Karst cave are good.

Laboratory tests were performed on rock samples extracted from surrounding rocks near the Karst cave. The tests included the compressive strength and permeability of Maokou limestone. Combining the laboratory test results, field investigation, and Hoek and Diederichs's research advances in deformation modulus of rock mass, HoekBrown strength theory was applied to obtain the mechanical parameters of rock mass by using Roclab software [35-37]. The rock mass calculation parameters of the Maokou limestone were obtained as shown in Table 1.

3.2. Calculation Model. The numerical model is established based on the in situ condition at the Qiyi coal mine in the south China. As shown in Figure 8, the simulation domain is $50 \mathrm{~m}$ long, $20 \mathrm{~m}$ wide, and $30 \mathrm{~m}$ deep, in which an excavation roadway in a semicircular arched shape is situated in the middle of the model, and confined Karst cave on the right edge of the model has a closely simplified ellipsoidal shape.

The left and right boundaries in this model are allowed to move along the vertical direction but are restrained in the horizontal direction. The bottom of the model is fixed. $\sigma_{1}=12.5 \mathrm{MPa}$ is applied on the upper surface of model to simulate crustal stress.

The boundary condition of seepage field is as follows: Karst cave hydraulic pressure is assumed to $1 \mathrm{MPa}, 2 \mathrm{MPa}$, $3 \mathrm{MPa}, 4 \mathrm{MPa}$, and $5 \mathrm{MPa}$, respectively, and the hydraulic pressure of the heading face is $0.1 \mathrm{MPa}$. No. 1 5 marked in Figure 5 simulates the driving by step. Footage by every step in the numerical simulation is $5 \mathrm{~m}$. When the water-proof rock pillar between the working face and Karst cave is less than $10 \mathrm{~m}$, for the purpose of studying the stability of the water-proof rock pillar with different thicknesses, footage by every step is $1 \mathrm{~m}$ in numerical simulation.

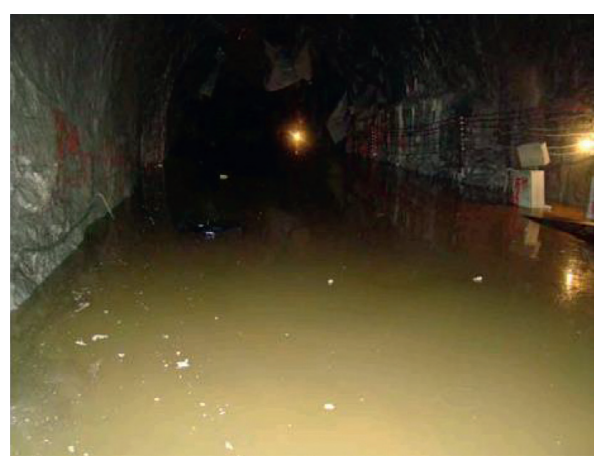

FIGURE 5: The picture of water discharge of the roadway in $8 \mathrm{~h}$ after water inrush.

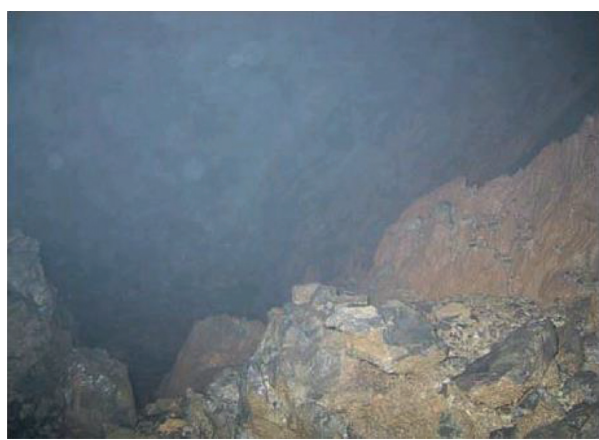

FIgURE 6: The scene photographs of the inside of the Karst cave.

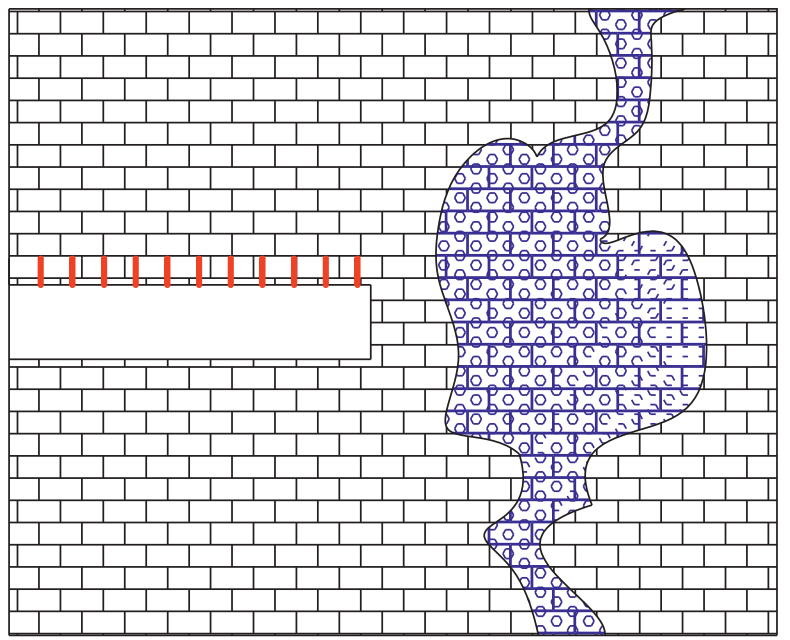

Figure 7: Vertical plane projection of Karst cave development.

As for an unstable water-proof rock pillar, water inrush from the Karst cave takes place. Considering that the supply of Karst water is not inexhaustible, it is assumed that the hydraulic pressure in the Karst cave attenuates dynamically in the course of water inrush, and the hydraulic pressure can be denoted as

$$
p=p_{0}\left(1-\frac{t}{T}\right)
$$

where $p_{0}$ is the initial cave hydraulic pressure, $T$ is the whole duration of Karst water inrush (it is assumed that $T=10 \mathrm{~h}$ in this simulation), and $t$ is the different water inrush time. 
TABLE 1: The rock mass calculation parameters of the Maokou limestone.

\begin{tabular}{|c|c|c|c|c|c|c|c|c|c|c|c|}
\hline $\begin{array}{l}\text { Density } \\
\left(\mathrm{Kg} / \mathrm{m}^{3}\right)\end{array}$ & $\begin{array}{c}\text { Water } \\
\text { absorption }\end{array}$ & $\begin{array}{l}\text { Saturated } \\
\text { coefficient }\end{array}$ & $\begin{array}{l}\text { Softening } \\
\text { coefficient }\end{array}$ & $\begin{array}{c}\text { Uniaxial } \\
\text { compression } \\
(\mathrm{MPa})\end{array}$ & $\begin{array}{c}\text { Tensile } \\
\text { strength } \\
(\mathrm{MPa})\end{array}$ & $\begin{array}{c}\text { Young } \\
\text { modulus } \\
(\mathrm{GPa})\end{array}$ & $\begin{array}{c}\text { Poisson } \\
\text { ratio }\end{array}$ & ity & $\begin{array}{c}\text { Cohesion } \\
(\mathrm{MPa})\end{array}$ & $\begin{array}{c}\text { Internal } \\
\text { frictionangle } \\
\left({ }^{\circ}\right)\end{array}$ & $\begin{array}{c}\text { Hydraulic } \\
\text { conductivity } \\
10^{-10} \mathrm{~m} \cdot \mathrm{s}^{-1} \\
\end{array}$ \\
\hline 5.2 & & 0 & 0 & 12.7 & 0.82 & 12.6 & 0.35 & 0.25 & 1.5 & 29.7 & 0.85 \\
\hline
\end{tabular}

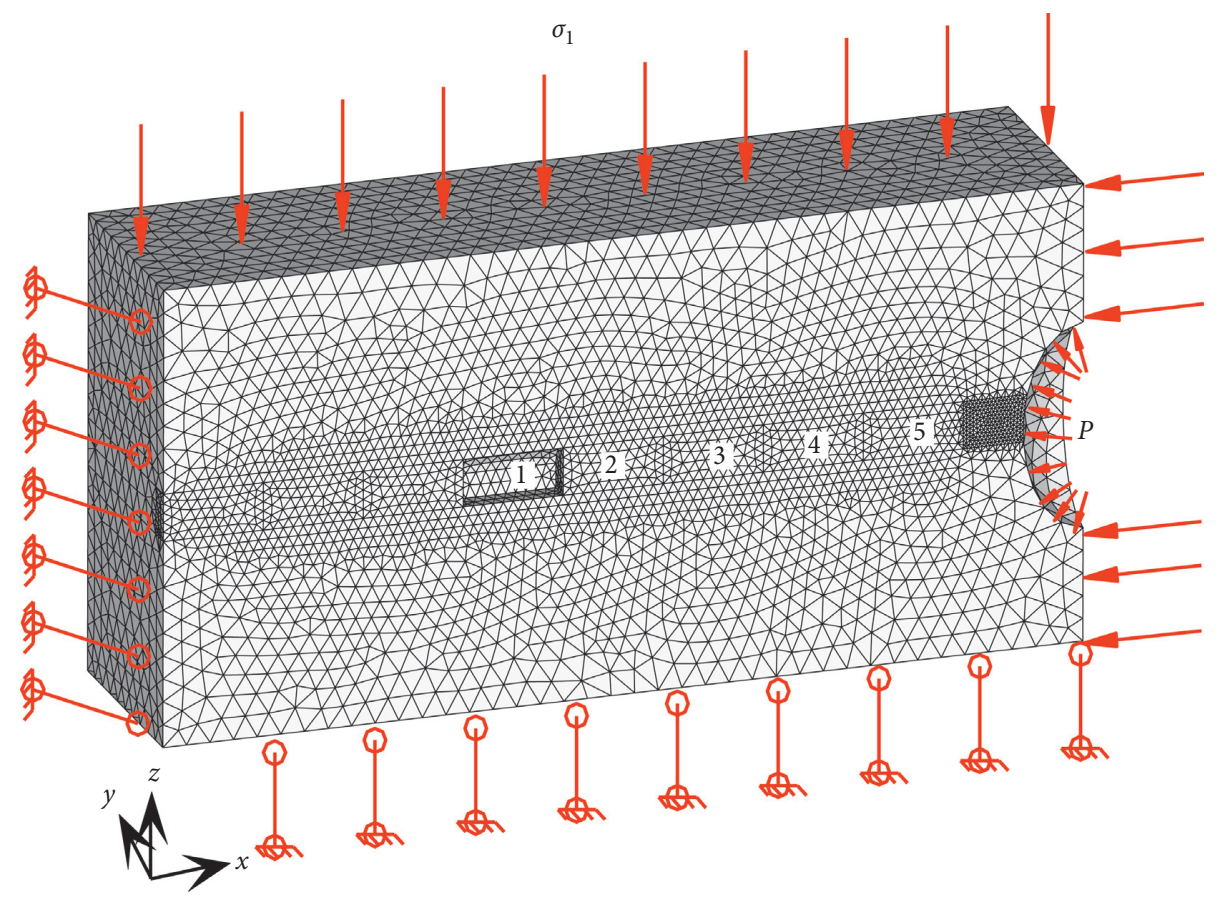

Figure 8: Numerical calculation model.

The roughness $\Delta$ of water inrush channel is assumed to $0.1 \mathrm{~m}$ [26]. Water-carrying section areas Sof the roadway is $10.6 \mathrm{~m}^{2}$, and the wetted perimeter $U$ is $10.4 \mathrm{~m}$. Suppose that the initial velocity of fluid flow $V_{\text {in }}$ is $0.1 \mathrm{~m} / \mathrm{s}$, which is a large value. It indicates that water flows in a hydraulic rough region at the very beginning. Using linkage analysis between solid-fluid coupling and the strength reduction method, the paper analyzes the stability of the water-proof rock pillar. Taking the hydraulic pressure $p=4 \mathrm{MPa}$ and the thickness $h=8 \mathrm{~m}$ of rock pillar as an example, the seepage properties of rock pillar and the evolution from stability to instability of the rock pillar are studied when the reduction factor gradually increases.

\section{Results}

4.1. Water-Proof Rock Pillar Instability. With gradually increase of the reduction factor, the strength parameters of the water-proof rock pillar gradually decrease. The hydraulic conductivity which is dependent of volumetric stress, hydraulic pressure, and plastic zones increases significantly under the action of disturbance stress and high hydraulic pressure.

The strength parameters of the water-proof rock pillar are $c=1.36 \mathrm{MPa}$ and $\tan \varphi=0.52$ when $F_{i}=1.10$. Under the strength, the plastic region of rock pillar is less; the hydraulic conductivity of the rock pillar is influenced mostly by volumetric stress and seepage pressure. The region which is nearly $1.5 \mathrm{~m}$ away from the working face is the enhanced hydraulic conductivity zone, which is about $3.25 \times 10^{-10} \sim 15.21 \times 10^{-10} \mathrm{~m} / \mathrm{s}$. The hydraulic conductivity for an undisturbed region in the middle of the rock pillar is about $0.70 \times 10^{-10} \sim 1.79 \times 10^{-10} \mathrm{~m} / \mathrm{s}$. The region near the Karst cave is also an enhanced hydraulic conductivity zone where the hydraulic conductivity is nearly $2.79 \times 10^{-10} \sim 5.68 \times 10^{-10} \mathrm{~m} / \mathrm{s}$. The hydraulic conductivity distribution map when reduction factor $F_{i}=1.10$ is shown in Figure 9.

When $F_{i}=1.54$, the strength parameters of the rock pillar are $c=0.97 \mathrm{MPa}, \tan \varphi=0.39$. Under the strength, about $85 \%$ of units in the water-proof rock pillar are in the plastic state, and the hydraulic conductivity of rock pillar increases at the speed of magnitude in comparison with when $F_{i}=1.54$ and it fluctuates between $1.47 \times 10^{-6} \sim 2.80 \times 10^{-6} \mathrm{~m} / \mathrm{s}$. The hydraulic conductivity distribution map when the reduction factor $F_{i}=1.54$ is shown in Figure 10.

When the reduction factor $F_{i}=1.10$, the seepage field distribution is calculated as shown in Figure 11. The seepage field of the surrounding rocks was disturbed because of 


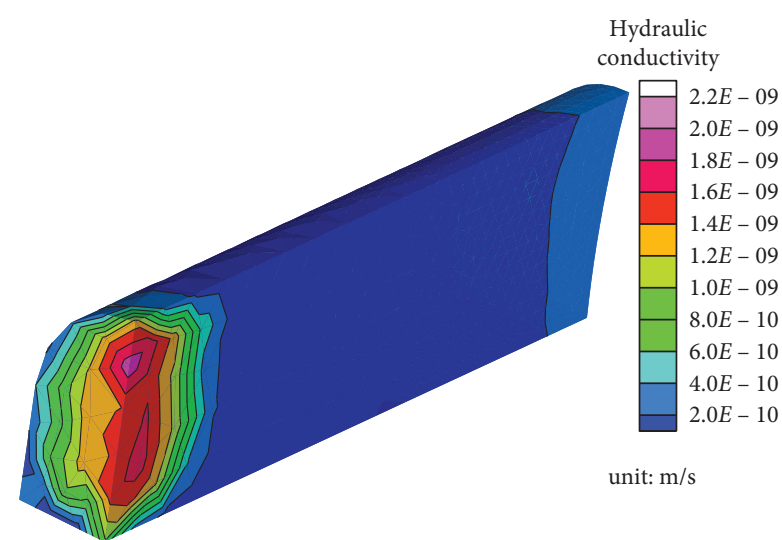

FIgURE 9: The hydraulic conductivity distribution map when thr reduction factor $F_{i}=1.10$.

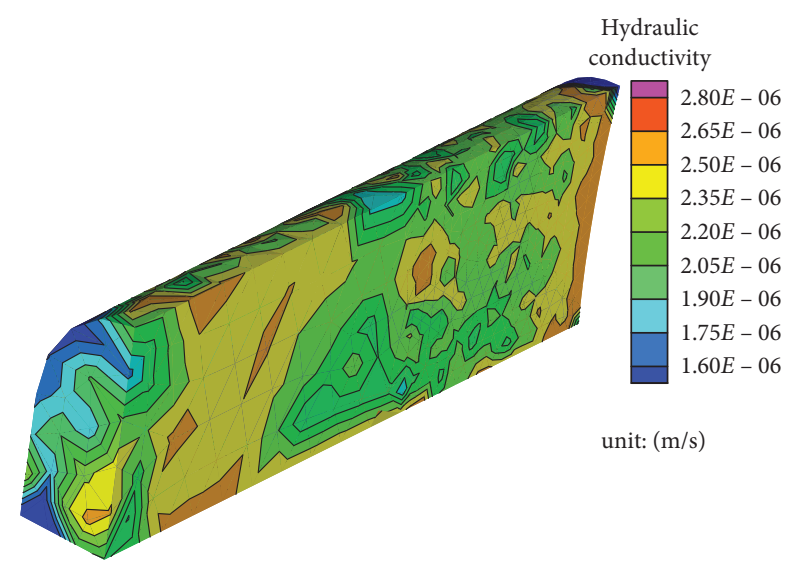

FIGURE 10: The hydraulic conductivity distribution map when the reduction factor $F_{i}=1.54$.

excavation. The seepage field adjusts continuously for the purpose of eliminating the high potential water pressure in the Karst cave. As Karst cave water discharges to the working face, seepage pressure progressively decreases from the Karst cave to working face. The mean seepage pressure gradient of the water-proof rock pillar is $0.5 \mathrm{MPa} / \mathrm{m}$, which brings the horizontal volumetric stress with the direction from Karst cave to working face, which is a driving force of instability of the water-proof rock pillar.

Based on linkage analysis on solid-fluid coupling and the strength reduction method, water discharges on the working face are achieved in the different reduction factors by FLAC $^{3 \mathrm{D}}$. Figure 12 illustrates that water discharge on the working face evolves from a low flow rate to a massive flow rate with the increase of the reduction factor. When $F_{i}=1.10 \sim 1.53$, the flow rate of the working face fluctuates from $2.05 \times 10^{-5} \mathrm{~m} / \mathrm{s}$ (when $F_{\mathrm{i}}=1.1$ ) to $7.47 \times 10^{-3} \mathrm{~m} / \mathrm{s}$ (when $\left.F_{\mathrm{i}}=1.53\right)$. This implies that when the reduction factor $F_{i}=1.10 \sim 1.53$, the water-proof rock pillar is stable, and water discharge on the working face is more seepage than water inrush. While the reduction factor $F_{i}=1.54 \sim 1.58$, water discharge on the working face increases abruptly and fluctuates from $0.025 \mathrm{~m}^{3} / \mathrm{s}$ (when $F_{\mathrm{i}}=1.54$ ) to $0.027 \mathrm{~m}^{3} / \mathrm{s}$ (when $F_{\mathrm{i}}=1.58$ ), due to nonlinear extension of the plastic

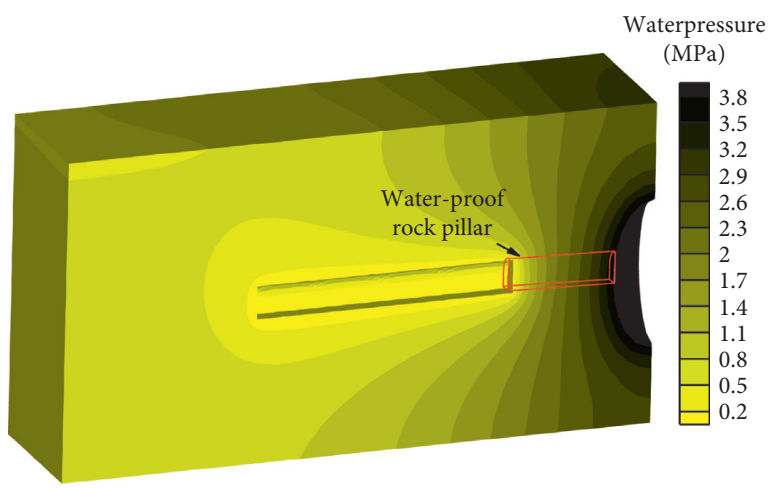

FIGURE 11: Distribution of seepage field of the surrounding rocks when the reduction factor $F_{i}=1.10$.

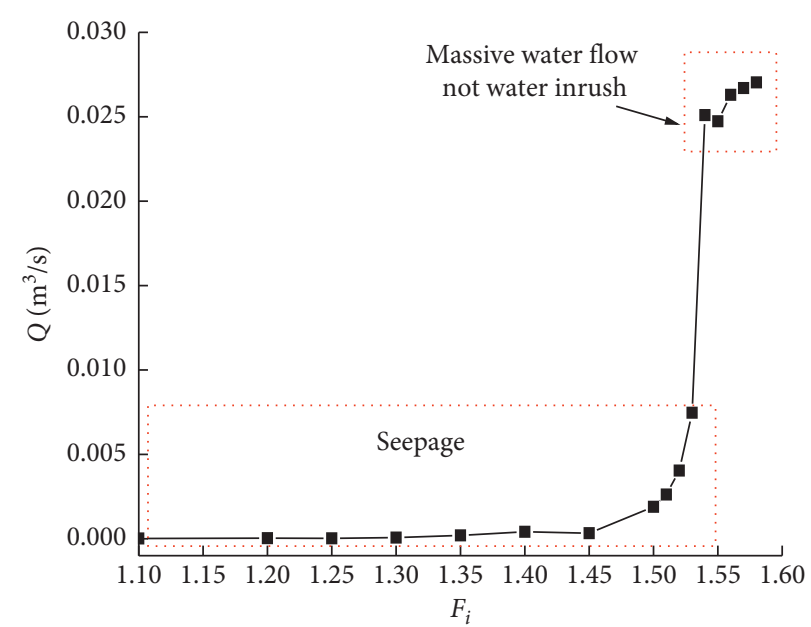

FIGURE 12: Water discharge of the working face evolves with the increase of reduction factor.

zone of rock pillar. Under the action of disturbance stress and high seepage volumetric stress, the displacement of the working face is about $15 \mathrm{~cm}$ by coupling calculation, when the reduction factor $F_{i}=1.54$, which is shown in Figure 13.

4.2. Water-Proof Rock Pillar Instability. The evolution of the percentage of plastic units in the water-proof rock pillar with the reduction factor is visualized in Figure 14. The plastic units in the water-proof rock pillar nonlinearly increase with the increment of reduction factor. When $F_{i} \geq 1.54$, the percentage of plastic units in the rock pillar mutates. The percentage of plastic units in the rock pillar is about $85 \%$ $87 \%$ when $F_{i}=1.54 \sim 1.58$. When $F_{i}=1.59$, the whole rock pillar is in the plastic state, the calculation has no convergence, rock pillar is in the instability stage, and water inrush from the confined Karst cave in a pipe flow form happens. It indicates that when the Karst cave internal pressure $p=$ $4 \mathrm{MPa}$ and water-proof rock pillar thickness $h=8 \mathrm{~m}$, the safety factor of the water-proof rock pillar is 1.59 .

Karst cave water inbursts into the roadway in a pipe flow form, when the water-proof rock pillar is in the instability stage. Water irruption quantity increases rapidly in the initial phase of water inrush. Thereafter, with the passage of 


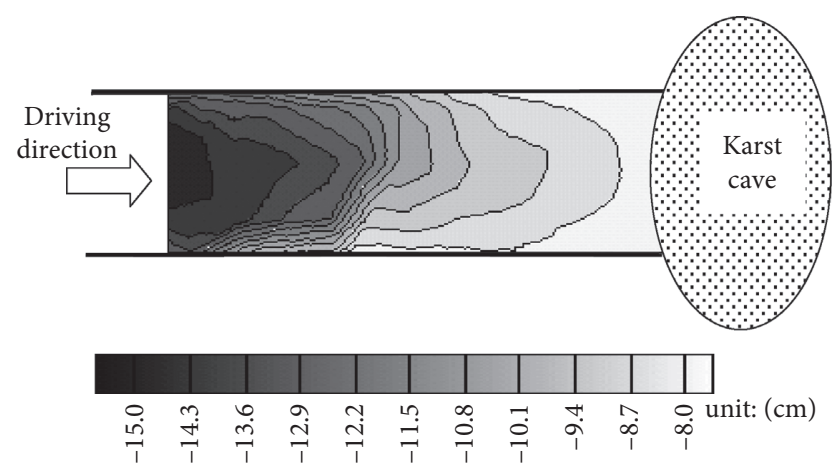

FIGURE 13: Horizontal displacement of the water-proof rock pillar when the reduction factor $F_{i}=1.54$.

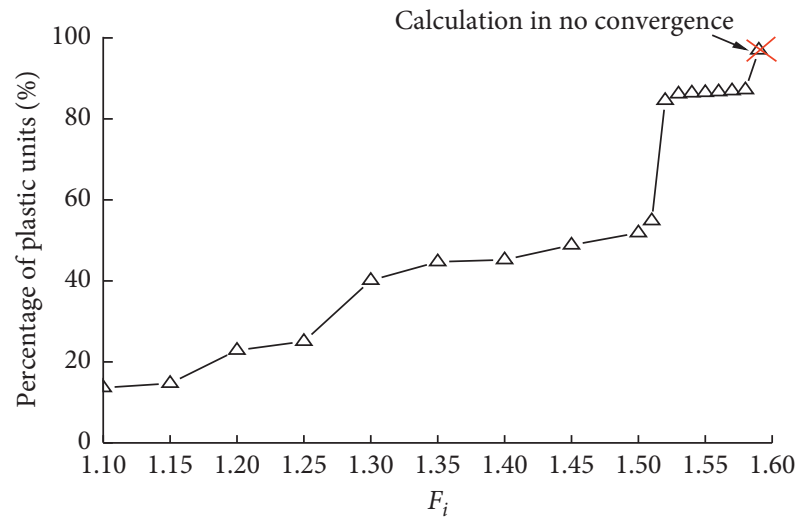

FIGURE 14: The evolution of the percentage of plastic units in the water-proof rock pillar with reduction factor.

time, the water irruption quantity attenuates unceasingly due to decrease of the supply of Karst water. In the calculation program, the evolution law of flow rate in the roadway during the process of water inrush is gained by pipe flow analysis illustrated in Figure 15. Water irruption quantity reaches the peak $\left(Q_{\max }=1.27 \mathrm{~m}^{3} / \mathrm{s}\right)$ in short time $(t=2.64 \mathrm{~h})$. Thereafter, water irruption quantity decreases rapidly. The results of numerical simulation agree well with practical flow law of confined Karst cave water inrush [38-40].

The evolution law of water pressure on roadway transverse sections where is $3 \mathrm{~m}, 8 \mathrm{~m}, 13 \mathrm{~m}$, and $18 \mathrm{~m}$ away from the karst cave is visualized in Figure 16. With the increase in water inrush time, the water pressure in the roadway quickly increases and then attenuates after reaching the peak. Owing to hydraulic losses in the roadway, the water pressure in the roadway becomes smaller and smaller, when the distance from the Karst cave is longer and longer.

The water pressure distribution in the roadway is obtained by pipe analysis as shown in Figure 17. Due to the instability of the water-proof rock pillar, Karst water pours into the roadway with an dramatic increase in the water pressure in the roadway. With the development of water inrush time, hydraulic gradient in the roadway declines continuously, for example, when $t=3.53 \mathrm{~h}$, the mean hydraulic gradient in the roadway is 5.6 much as that when

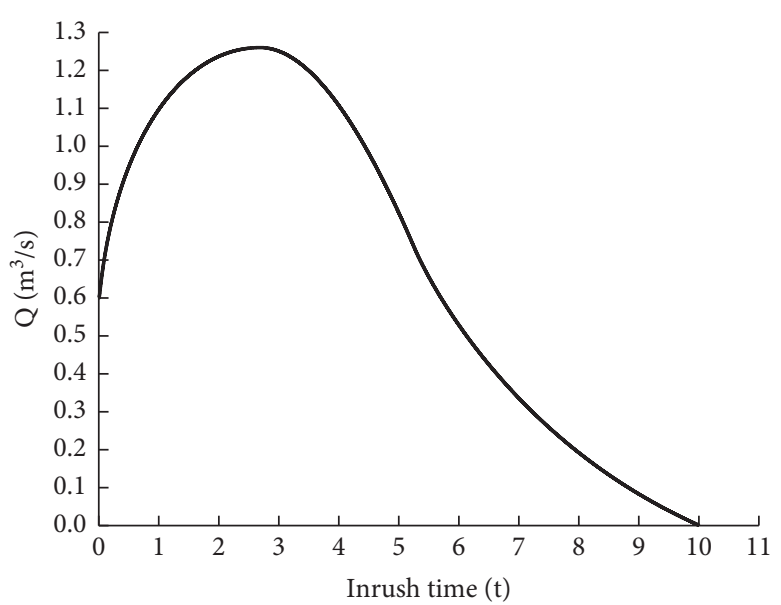

FIgURE 15: The evolution law of water discharge in the roadway during the process of water inrush.

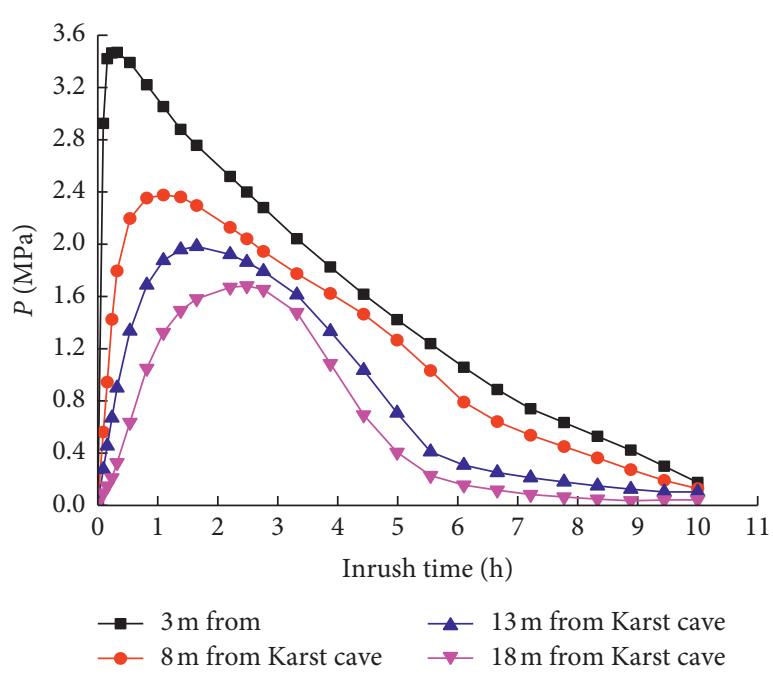

FIgURE 16: The evolution law of water pressure on roadway transverse sections which are $3 \mathrm{~m}, 8 \mathrm{~m}, 13 \mathrm{~m}$, and $18 \mathrm{~m}$ away from karst cave.

$t=9.44 \mathrm{~h}$. Owing to the hydraulic gradient decaying rapidly with the passage of time, resulting in the slowing down of water flow in the roadway, the hydraulic rough flow at the initial water inrush process changes into pipe laminar low finally.

4.3. Safety Factor of the Water-Proof Rock Pillar. By the linkage analysis of solid-fluid coupling theory and the strength reduction method adopted, the safety factor of the water-proof rock pillar is gained when karst cave hydraulic pressure $p$ in the Karst cave and calculation thickness $h$ of the water-proof rock pillar are different. In Figure 14, when the Karst cave hydraulic pressures are $1 \mathrm{MPa}, 2 \mathrm{MPa}, 3 \mathrm{MPa}$, $4 \mathrm{MPa}$, and $5 \mathrm{MPa}$, respectively, and the calculation thickness of the rock pillar is $3 \mathrm{~m}, 4 \mathrm{~m}, 5 \mathrm{~m}, 6 \mathrm{~m}, 7 \mathrm{~m}, 8 \mathrm{~m}, 9 \mathrm{~m}$, and $10 \mathrm{~m}$ separately, and the relationship curves of safety factor $F_{S}$ and karst cave hydraulic pressure $p$ and calculation thickness $h$ of the rock pillar are achieved. 


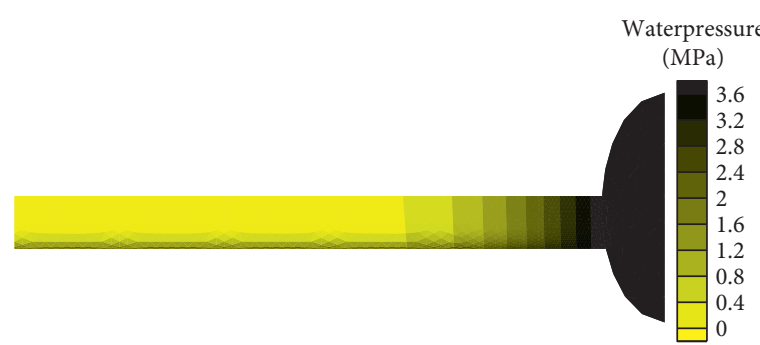

(a)

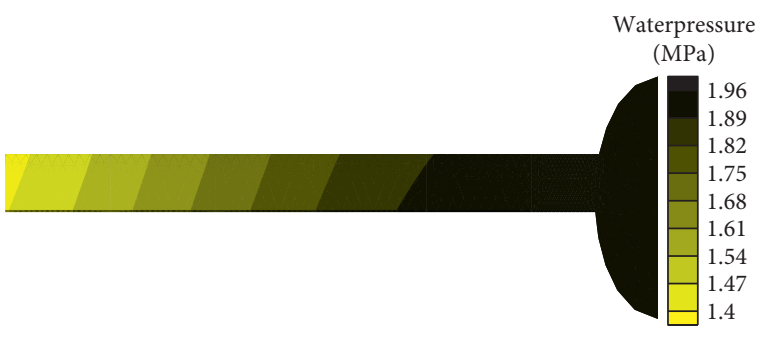

(b)

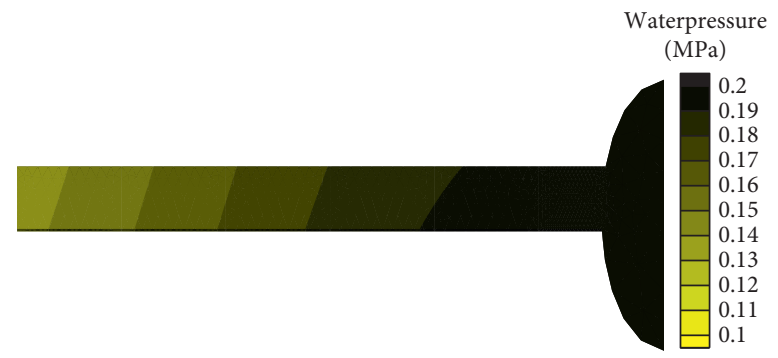

(c)

Figure 17: The water pressure distributions in the roadway by pipe analysis analysis in different times. (a) $t=0.14 \mathrm{~h}$. (b) $t=3.53 \mathrm{~h}$. (c) $t=9.44 \mathrm{~h}$.

Figure 18 displays that the safety factor $F_{S}$ increases gradually with the increase of calculation safety thickness $h$ of the rock pillar, which is fitted by the exponential function:

$$
F_{S}=a+b \exp (c h)
$$

where $F_{S}$ is the safety factor of the water-proof rock pillar; $h$ is the calculation safety thickness of the water-proof rock pillar; and $a, b$, and $c$ are undetermined coefficients.

The relation between safety factor $F_{S}$ of the water-proof rock pillar and calculation safety thickness $h$ of the waterproof rock pillar under different Karst cave water pressures $p$ is obtained by using equation (19), which is demonstrated in Table 2. If $F_{S}=1.5$ is considered as the yardstick of stability of the water-proof rock pillar, some yardsticks are educed:

When $F_{S} \geq 1.5$, the water-proof rock pillar is stable.

When $F_{S}<1.5$, the water-proof rock pillar is unstable.

Conclusions can be drawn from Table 2 that the calculation safety thickness of the water-proof rock pillar should be thickened with the increment of Karst hydraulic pressure, such as when the Karst cave hydraulic pressures are $1 \mathrm{MPa}$ and $5 \mathrm{MPa}$, respectively, and the calculation safety thickness of the water-proof rock pillar is $5.18 \mathrm{~m}$ and $9.32 \mathrm{~m}$, respectively. The calculation safety thickness of the waterproof rock pillar is $4.14 \mathrm{~m}$ more when the hydraulic pressure $p=5 \mathrm{MPa}$ than when the hydraulic pressure $p=1 \mathrm{MPa}$. This is because with the increase of Karst hydraulic pressure, the seepage volumetric stress in the water-proof rock pillar increases, which directly leads to the enhancement of lateral thrust along the direction of the working face, and the calculation thickness should be thickened.

4.4. Safety Thickness of Water-Proof Rock Pillar Setting. Drilling and blasting is mostly applied in mines in southern China, and the coupling analysis model is used without

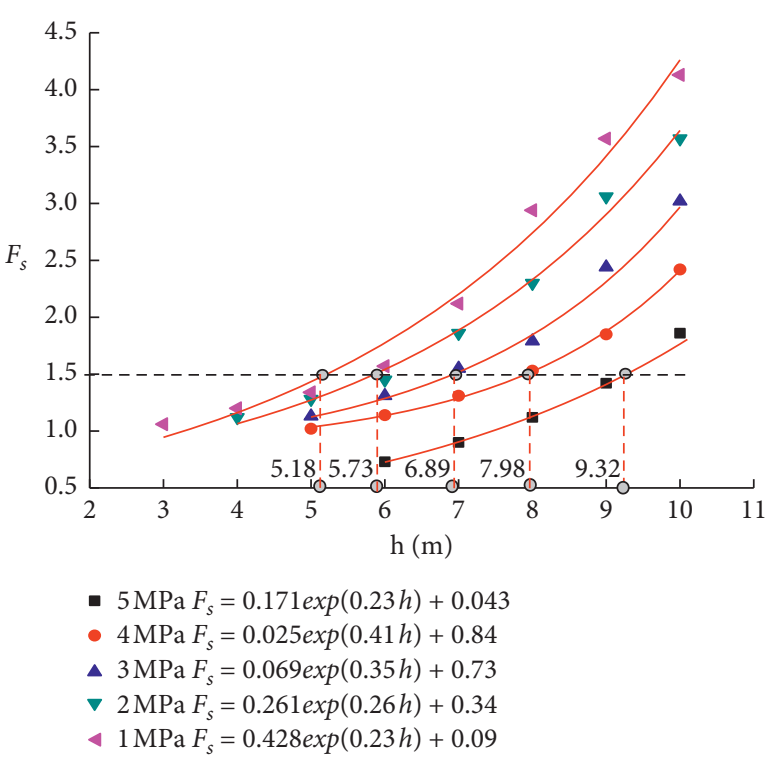

FIgURE 18: Variation relation curves between safe factor and calculation safety thickness of the water-proof rock pillar.

considering the disturbance of blasting to the surrounding rocks before the working face. Based on the experimental research and numerical analysis results [41-43], the disturbance depth of ordinary blasting, smooth blasting, and presplitting blasting to the surrounding rocks is about $1.5 \mathrm{~m}$; meanwhile, disturbance depth increases with the increment of a single segment explosive dosage. So, safety thickness of water-proof rock pillar setting in mining engineering is the sum of the blasthole depth $h_{1}$, blasting disturbance depth $h_{2}$, and safety caculation thickness $h_{3}$ of the water-proof rock pillar, which can be denoted as follows: 
TABLE 2: The relation between safety factor $F_{S}$ and thickness $h$ of the water-proof rock pillar under different karst cave water pressures.

\begin{tabular}{lcc}
$\begin{array}{l}\text { Karst cave water } \\
\text { pressure }(\mathrm{MPa})\end{array}$ & $\begin{array}{c}\text { The relation between safety factor } F_{S} \text { and thickness of } \\
\text { water-proof rock pillar } h\end{array}$ & $\begin{array}{c}\text { The calculation safety thickness of water-proof rock } \\
\text { pillar when safety factor } F_{S}=1.5(\mathrm{~m})\end{array}$ \\
\hline 1 & $F s=0.428 \exp (0.23 \mathrm{~h})+0.09$ & 5.18 \\
2 & $F s=0.261 \exp (0.26 \mathrm{~h})+0.34$ & 5.73 \\
3 & $F s=0.069 \exp (0.35 \mathrm{~h})+0.73$ & 7.99 \\
4 & $F s=0.025 \exp (0.41 \mathrm{~h})+0.84$ & 9.32 \\
5 & $F s=0.171 \exp (0.23 \mathrm{~h})+0.043$ & \\
\hline
\end{tabular}

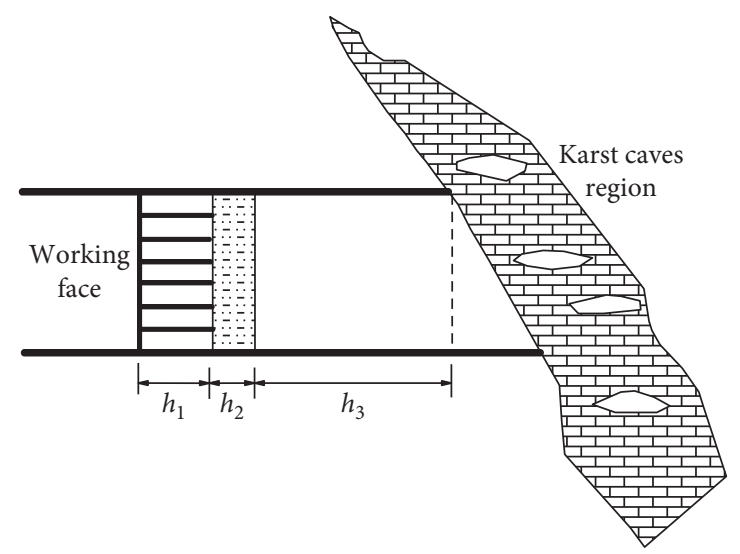

FIGURE 19: Schematic diagram of safety thickness of water-proof rock pillar setting in mining engineering.

TABLE 3: Safety thickness of water-proof rock pillar setting in the Maokou limestone for the Qiyi coal mine.

\begin{tabular}{lcccc}
\hline $\begin{array}{l}\text { Kars water } \\
\text { pressure }(\mathrm{MPa})\end{array}$ & $\begin{array}{c}\text { Blasthole depth } \\
h_{1}(\mathrm{~m})\end{array}$ & $\begin{array}{c}\text { Blasting disturbance } \\
\text { depth } h_{2}(\mathrm{~m})\end{array}$ & $\begin{array}{c}\text { Calculation safety thickness of } \\
\text { rock pillar } h_{3}(\mathrm{~m})\end{array}$ & $\begin{array}{c}\text { Safety thickness of water-proof rock } \\
\text { pillar setting }(\mathrm{H} / \mathrm{m})\end{array}$ \\
\hline 1.0 & 2.5 & 1.5 & 5.18 & 9.18 \\
2.0 & 2.5 & 1.5 & 5.73 & 9.73 \\
3.0 & 2.5 & 1.5 & 6.89 & 10.89 \\
4.0 & 2.5 & 1.5 & 7.98 & 11.98 \\
5.0 & 2.5 & 1.5 & 7.98 & 13.32 \\
\hline
\end{tabular}

$$
H=h_{1}+h_{2}+h_{3} \text {, }
$$

where $H$ is the safety thickness of water-proof rock pillar setting in mining engineering; $h_{1}$ is the blasthole depth; $h_{2}$ is the blasting disturbance depth; and $h_{3}$ is the calculation safety thickness $h$ of water-proof rock pillar based on equation (19).

The schematic diagram of safety thickness of water-proof rock pillar setting of a confined Karst cave before a roadway is visualized in Figure 19. The calculation safety thickness $h_{3}$ of the rock pillar is gained by the way proposed in this paper. Table 3 illustrates safety thickness of water-proof rock pillar setting for confined the Karst cave in the Qiyi mine based on equation (20). Based on Table 3, when hydraulic pressures of the Karst cave are from $1.0 \mathrm{MPa}$ to $5.0 \mathrm{MPa}$, the safety thickness of water-proof rock pillar setting is from $9.2 \mathrm{~m}$ to $13.4 \mathrm{~m}$. According to regulations of mine water control, when the hydraulic pressure is less than 1.0 MPa, the advanced horizontal distance of the pilot hole for detecting water should not be less than $10 \mathrm{~m}$, and the length of water stop casing is more than $5 \mathrm{~m}$ for a rock roadway; with the increase of hydraulic pressure, the advanced horizontal distance and the length of water stop casing must increase correspondingly; when the hydraulic pressure is more than 3.0 MPa, the advanced horizontal distance is more than $25 \mathrm{~m}$ and the length of water stop casing is more than $20 \mathrm{~m}$. Base on the research results of this paper, if regulations of mine water control are strictly executed, especially regulations about exploring water and drilling advanced distance and the length of water stop casing, the chance for occurrence of water inrush would be extremely small because the advanced distance of pilot hole for detecting water and the length of water stop casing regulated in regulations of mine water control are more than the safety thickness of the water-proof rock pillar setting proposed in this paper. In a Karst coal mine, when hydrogeology condition is complicated or even extremely complicated, the rule of exploring before mining should be obeyed.

Water inrush accident induced by confined water breaking rock pillar happened on the heading face with $-160 \mathrm{~m}$ level of the Qiyi mine. The investigation suggested that the Karst cave with a volume of $20 \mathrm{~m} \times 6 \mathrm{~m} \times 20 \mathrm{~m}$ was 
some $3 \sim 4 \mathrm{~m}$ away from the face. That is to say, the waterproof rock pillar between the Karst cave and working face was about 3 4 $\mathrm{m}$. Even worse, as the surface water connected well with the Karst cave water, the hydraulic pressure in the Karst cave was about 3.5 4.0 MPa. Based on Table 3, the safety thickness of water-proof rock pillar setting should be 11 12 $\mathrm{m}$. The water-proof rock pillar with a thickness of $3 \sim 4 \mathrm{~m}$ did not have the ability of preventing water inrush, let alone safety margins.

\section{Conclusions}

(1) The linkage analysis of solid-fluid coupling and the strength reduction method to study the Karst cave water inrush is proposed. The interaction of disturbance stress and high seepage volumetric stress to the water-proof rock pillar gives rise to instability of the water-proof rock pillar. Accompanying with mechanical instability of water-proof rock, Karst cave water inrush is deemed a conversion process of the "seepage to pipe flow."

(2) Equivalent hydraulic conductivity of pipe flow for confined Karst cave water inrush is introduced, and a nonlinear seepage-pipe coupling model of confined Karst cave water inrush is established. Combining the nonlinear seepage-pipe coupling model with the strength reduction method, the linkage analysis of fluid solid coupling and the strength reduction method is constructed to study the whole process of water inrush

(3) Taking the water inrush accident of Shibaijing of the Qiyi mine as an example, it is proposed that the thickness of the water-proof rock pillar whose safety factor equals 1.5 is regarded as the calculating safety thickness of the water-proof rock pillar, and safety thickness of water-proof rock pillar setting in mining engineering is equal to the sum of the blasthole depth, blasting disturbance depth, and the calculating safety thickness of the water-proof rock pillar.

(4) The reason leading to Karst water inrush of the Qiyi mine is that due to the absence of advanced boreholes, the water-proof rock pillar is set so small that it cannot possess a safety margin, and the confined Karst cave water breaks the water-proof rock pillar and bursts out.

\section{Data Availability}

The data used to support the findings of this study are included within the article.

\section{Conflicts of Interest}

The authors declare that they have no conflicts of interest.

\section{Acknowledgments}

This research was supported by the National Natural Science Foundation of China (nos. 51774131 and 51274097) and the CRSRI Open Research Program (CKWV2017508/KY).

\section{References}

[1] Q. Wu and M. Wang, "Characterization of water bursting and discharge into underground mines with multilayered groundwater flow systems in the North China coal basin," Hydrogeology Journal, vol. 14, no. 6, pp. 882-893, 2006.

[2] Q. Wu, M. Wang, and X. Wu, "Investigations of groundwater bursting into coal mine seam floors from fault zones," International Journal of Rock Mechanics and Mining Sciences, vol. 41, no. 4, pp. 557-571, 2004.

[3] B. Yu, W. Zhu, and J. Xu, "Numerical simulation of surface subsidence characteristics during deep mining," Journal of Mining and Safety Engineering, vol. 24, no. 4, pp. 422-426, 2007.

[4] Y. Zhao, L. Zhang, W. Wang, J. Tang, H. Lin, and W. Wan, "Transient pulse test and morphological analysis of single rock fractures," International Journal of Rock Mechanics and Mining Sciences, vol. 91, pp. 139-154, 2017.

[5] Y. X. Wang, S. Y. Wang, Y. L. Zhao, P. P. Guo, Y. Liu, and P. Cao, "Blast Induced Crack Propagation and Damage Accumulation in Rock Mass Containing Initial Damage," Shock and Vibration, vol. 2018, pp. 1-18, 2018.

[6] L. Dong, D. Sun, X. Li, J. Ma, L. Zhang, and X. Tong, "Interval non-probabilistic reliability of surrounding jointed rockmass considering microseismic loads in mining tunnels," Tunnelling and Underground Space Technology, vol. 81, pp. 326-335, 2018.

[7] L. J. Dong, W. Zou, D. Y. Sun, and X. J. Tong, "Some Developments and New Insights for Microseismic/Acoustic Emission Source Localization," Shock and Vibration, vol. 2019, pp. 1-15, 2019.

[8] Y. Zhao, Y. Wang, W. Wang, W. Wan, and J. Tang, "Modeling of non-linear rheological behavior of hard rock using triaxial rheological experiment," International Journal of Rock Mechanics and Mining Sciences, vol. 93, pp. 66-75, 2017.

[9] Y. L. Zhao, L. Y. Zhang, W. J. Wang, W. Wan, and W. H. Ma, "Separation of elastoviscoplastic strains of rock and a nonlinear creep model," International Journal of Geomechanics, vol. 18, no. 1, 2018.

[10] K. Peng, J. Zhou, Q. Zou, and X. Song, "Effect of loading frequency on the deformation behaviours of sandstones subjected to cyclic loads and its underlying mechanism," International Journal of Fatigue, vol. 131, Article ID 105349, 2020.

[11] J. Zhang and B. Shen, "Coal mining under aquifers in China: a case study," International Journal of Rock Mechanics and Mining Sciences, vol. 41, no. 4, pp. 629-639, 2004.

[12] Y. L. Gong and F. Z. Wan, "Impact of karst water on coal mining in North China," Environmental Geology, vol. 49, pp. 449-457, 2006.

[13] C. S. Wang, H. B. Bai, and S. C. Liu, "Mine water issues in China," in Proceedings of the IMWA 2010 Symposium Sydney, vol. 445-448, Mine Water and Innovative Thinking, Nova Scotia, Canada, 2010.

[14] H. Keqiang, Y. Jia, F. Wang, and Y. Lu, "Overview of karst geo-environments and karst water resources in north and south China," Environmental Earth Sciences, vol. 64, no. 7, pp. 1865-1873, 2011.

[15] X. X. Miao, A. Wang, Y. J. Sun et al., "Research on theory of mining with water resources protection and its application to arid and semi-arid mining region," Chinese Journal of Rock Mechanics and Engineering, vol. 28, no. 2, pp. 217-227, 2009.

[16] K. Q. He, R. L. Wang, and W. F. Jiang, "Groundwater inrush channel detection and curtain grouting of the Gaoyang iron 
ore mine, China," Mine Water and the Environment, vol. 31, no. 4, pp. 297-306, 2012.

[17] W. J. Wang, Y. L. Zhao, Q. F. Li et al., "Disaster mechanism of karst water bursting in mine," Journal of China Coal Society, vol. 35, no. 3, pp. 443-448, 2010.

[18] G. J. Wang, "The discussion of karst water dam age prevention in Huayingshan mine area," Journal of North China Institute of Science and Technology, vol. 6, no. 4, pp. 96-100, 2009.

[19] S. H. Zhou, "Maokou limestone karstic water flooding and harnessing in Songzao coalmine, chongqing," Coal Geology of China, vol. 17, no. 5, pp. 65-77, 2005.

[20] Y. L. Zhao, J. Z. Tang, Y. Chen, L. Y. Zhang, W. J. Wang, and J. P. Liao, "Hydromechanical coupling tests for mechanical and permeability characteristics of fractured limestone in complete stress-strain process," Environmental Earth Sciences, vol. 76, no. 1, pp. 1-18, 2017.

[21] C. L. Wang, L. Pan, Y. Zhao, Y. Zhang, and W. Shen, "Analysis of the pressure pulse propagation in rock: a new approach to simultaneously determine permeability, porosity, and adsorption capacity," Rock Mechanics and Rock Engineering, vol. 52, no. 11, pp. 4301-4317, 2019.

[22] Ministry of Coal Industry, Regulations for Mine Water Prevention and Control, Coal Industry Publication Press, Beijing, China, 2009.

[23] H. Q. Zhang, Y. N. He, C. A. Tang, B. Ahmad, and L. J. Han, "Application of an improved flow-stress-damage model to the criticality assessment of water Inrush in a mine: a case study," Rock Mechanics and Rock Engineering, vol. 42, no. 6, pp. 911-930, 2009.

[24] Y. Wang, Q. Chen, and Y. Y. Wei, "Application of infrared acquisition technology to prediction of water inrush in Yuanliangshan tunnel," Chinese Journal of Rock Mechanics and Engineering, vol. 22, no. 5, pp. 855-857, 2003.

[25] C. X. Chen, "Groundwater flow model and simulation method in triple media of karst tube-fissure-pore," Earth Sciences, vol. 20, no. 4, pp. 361-366, 1995.

[26] S. H. Liu and S. C. Yu, "Effect of turbulent boundary layer to a small step change in wall roughness," Journal of Hydrodynamics, vol. 13, no. 1, pp. 35-40, 1998.

[27] Y. L. Zhao, Y. Wang, and L. Tang, "The compressive-shear fracture strength of rock containing water based on Druker-Prager failure criterion," Arabian Journal of Geosciences, vol. 12, p. 452, 2019

[28] Y. Zhao, P. He, Y. Zhang, and C. Wang, "A new criterion for a toughness-dominated hydraulic fracture crossing a natural frictional interface," Rock Mechanics and Rock Engineering, vol. 52, no. 8, pp. 2617-2629, 2019.

[29] J. J. Meng, Y. X. Wang, Y. L. Zhao, H. Ruan, and Y. Liu, "Stability analysis of earth slope using combined numerical analysis method based on DEM and LEM," Tehnički Vjesnik, vol. 25, no. 5, pp. 1265-1273, 2018.

[30] Y. Zhao, L. Zhang, W. Wang, C. Pu, W. Wan, and J. Tang, "Cracking and stress-strain behavior of rock-like material containing two flaws under uniaxial compression," Rock Mechanics and Rock Engineering, vol. 49, no. 7, pp. 26652687, 2016.

[31] C. Wang, Y. Zhao, Y. L. Zhao, and W. Wan, "Study on the interaction of collinear cracks and wing cracks and cracking behavior of rock under uniaxial compression," Advances in Civil Engineering, vol. 2018, pp. 1-10, 2018.

[32] Y. X. Wang, H. Zhang, H. Lin, Y. Zhao, and Y. Liu, "Fracture behaviour of central-flawed rock plate under uniaxial compression," Theoretical and Applied Fracture Mechanics, vol. 106, 2020.
[33] Y. Zhao, Y. Wang, W. Wang, L. Tang, Q. Liu, and G. Cheng, "Modeling of rheological fracture behavior of rock cracks subjected to hydraulic pressure and far field stresses," Theoretical and Applied Fracture Mechanics, vol. 101, pp. 59-66, 2019.

[34] L. J. Dong, W. W. Shu, X. B. Li, Z. Zhou, F. Gong, and X. Liu, "Quantitative evaluation and case study of risk degree for underground goafs with multiple indexes considering uncertain factors in mines," Geofluids, vol. 2017, pp. 1-15, 2017.

[35] Q. Wu, L. Chen, B. Shen, B. Dlamini, S. Li, and Y. Zhu, "Experimental investigation on rockbolt performance under the tension load," Rock Mechanics and Rock Engineering, vol. 52, no. 11, pp. 4605-4618, 2019.

[36] Y. L. Zhao, L. Y. Zhang, W. J. Wang et al., "Creep behavior of intact and cracked limestone under multi-level loading and unloading cycles," Rock Mechanics and Rock Engineering, vol. 50, no. 6, pp. 1-16, 2017.

[37] J. Chen, H. Peng, J. Fan, X. Zhang, W. Liu, and D. Jiang, "Microscopic investigations on the healing and softening of damaged salt by uniaxial deformation from CT, SEM and NMR: effect of fluids (brine and oil)," RSC Advances, vol. 10, no. 5, pp. 2877-2886, 2020.

[38] X. R. Liu, X. D. Zhang, and M. Huang, "Delay characteristics and risk mitigation of karst water burst flood of tunnels," Chinese Journal of Geotechnical Engineering, vol. 33, no. 9, pp. 1326-1332, 2011.

[39] L. Zhang and J. A. Franklin, "Prediction of water flow into rock tunnels: an analytical solution assuming an hydraulic conductivity gradient," International Journal of Rock Mechanics and Mining Sciences \& Geomechanics Abstracts, vol. 30, no. 1, pp. 37-46, 1993.

[40] T. Li, T. Mei, X. Sun, Y. Lv, J. Sheng, and M. Cai, "A study on a water-inrush incident at Laohutai coalmine," International Journal of Rock Mechanics and Mining Sciences, vol. 59, pp. 151-159, 2013.

[41] J. Y. Qi, "The Influence of tunnel blasting method for surrounding," Railway Engineering, vol. 7, pp. 4-7, 1979.

[42] G. Wang, Y. Luo, X. Li, T. Liu, R. Ma, and D. Qu, "Study on dynamic mechanical properties and meso-damage mechanism of jointed rock under impact load," European Journal of Environmental and Civil Engineering, vol. 45, pp. 1-17, 2019.

[43] W. X. Zheng, Y. L. Zhao, and Q. W. Bu, "The coupled control of floor heave based on a composite structure consisting of bolts and concrete antiarches," Mathematical Problems Engineering, vol. 2018, pp. 1-14, 2018. 